Contents

List of Figures $\quad$ ix

List of Tables $\quad$ xvii

Preface $\quad$ xix

John M. Marston, Jade d'Alpoim Guedes, and Christina Warinner

I. Paleoethnobotanical Method and Theory in the Twenty-First Century

John M. Marston, Christina Warinner, and Jade d'Alpoim Guedes I

Part I: Formation Processes

2. Formation Processes of the Macrobotanical Record Daphne E. Gallagher I9

3. Formation and Taphonomic Processes

Affecting Starch Granules

Amanda G. Henry 35

4. Formation Processes of Pollen and Phytoliths

Deborah M. Pearsall $\quad 5^{I}$ 
Part II: Recovery, Identification, and Data Management

5. Sampling Strategies in Paleoethnobotanical Analysis

Jade d'Alpoim Guedes and Robert Spengler $\quad 77$

6. Recovering Macrobotanical Remains: Current Methods and Techniques

Chantel E. White and

China P. Shelton 95

7. Laboratory Analysis and Identification of Plant Macroremains

Gayle Fritz and Mark Nesbitt $\quad$ IIS

8. Digitizing the Archaeobotanical Record

Christina Warinner and Jade d'Alpoim Guedes $\quad$ I47

Part III: Quantification and Analysis

9. Ratios and Simple Statistics in Paleoethnobotanical Analysis: Data Exploration and Hypothesis Testing John M. Marston ${ }_{16} 63$

Io. The Use of Multivariate Statistics within Archaeobotany Alexia Smith $\quad$ I8I

II. Analysis and Interpretation of Intrasite Variability in Paleoethnobotanical Remains: A Consideration and Application of Methods at the Ravensford Site, North Carolina

Amber M. VanDerwarker, Jennifer $V$. Alvarado, and Paul Webb 205 
I2. Intersite Variation within Archaeobotanical

Charred Assemblages: A Case Study

Exploring the Social Organization of

Agricultural Husbandry in Iron Age and

Roman Britain

Chris J. Stevens 235

Part IV: Integration of

Paleoethnobotanical Data

I3. Peopling the Environment: Interdisciplinary

Inquiries into Socioecological Systems

Incorporating Paleoclimatology and

Geoarchaeology

Timothy C. Messner and

Gary E. Stinchcomb 257

I4. From the Ground Up: Advances in Stable

Isotope-Based Paleodietary Inference

Christina Warinner 275

I5. Ancient Biomolecules from Archaeobotanical

Remains

Nathan Wales, Kenneth Andersen, and

Enrico Cappellini 293

16. A Landscape Context for Paleoethnobotany:

The Contribution of Aerial and Satellite

Remote Sensing

Jesse Casana 315

Part V: Interpretation

I7. Human Behavioral Ecology and Paleoethnobotany Kristen J. Gremillion 339 
I8. Documenting Human Niche Construction in the Archaeological Record

Bruce D. Smith 355

19. Paleoethnobotanical Analysis, Post-Processing

Shanti Morell-Hart $37{ }^{I}$

References Cited 39I

About the Contributors $53 \mathbf{I}$

Index $\quad 535$ 
Paleoethnobotanical

Method and Theory in the

Twenty-First Century

John M. Marston,

The origins of the study of relationships between people and plants in the past began as early as the nineteenth century with the identification of desiccated plant remains recovered from rockshelters in the American Southwest (Ford 2003:xii; 2004:x; Pearsall 2000:I) and waterlogged remains from Swiss lake-dwelling sites (Hastorf 1999:55). This field of study, first termed ethno-botany, today is termed either paleoethnobotany or archaeobotany, with the two synonymous terms generally preferred in North America and Europe, respectively (figure I.I). Paleoethnobotany expanded tremendously as a field in the second half of the twentieth century, as reflected in the growing number of publications since the r97os (see the extensive bibliographies in Hastorf 1999 and Pearsall 2000), and continues to make substantial contributions to archaeology today.

This volume is conceived as a reflection on the state of the field after the first decade of the twenty-first century. Paleoethnobotany has changed dramatically since its earliest days and since the publication of the first seminal volumes in the I970s and I980s (Hastorf and Popper 1988; Pearsall 1989; Renfrew I973; van Zeist and Casparie I984; van Zeist et al. 199I). It is time for a new and updated overview of the methods and theory of paleoethnobotany that addresses what we do and why we do it. This volume assembles a diverse group of authors to write about their areas of expertise in the practice and theory of paleoethnobotany. We cover topics from the formation processes of plant remains

Christina Warinner, and Jade d’Alpoim Guedes

DOI: 10.5876/9781607323167.coor 

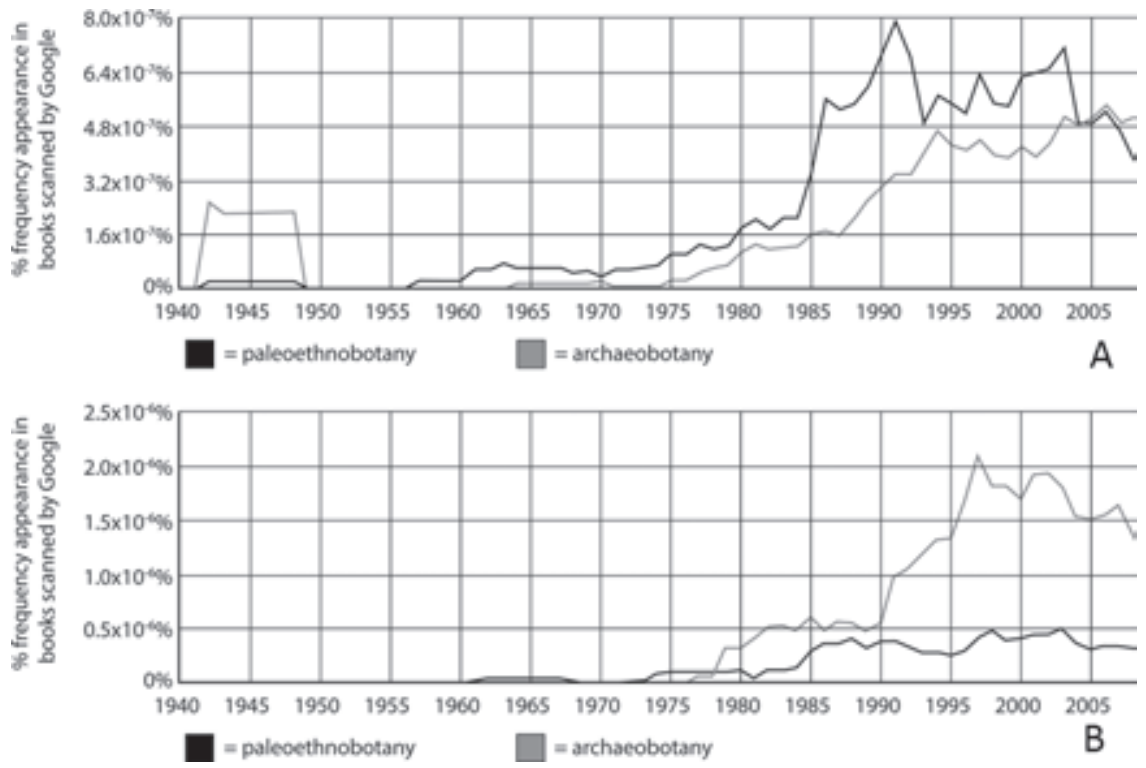

FigURE I.I. Relative trends in the use of the terms paleoethnobotany and archaeobotany in American (a) and British (b) books published between 1940 and 2008, as three-year running averages, originally created using Google Ngram Viewer (https://books. google. com/ngrams, searched May 30, 2013). These data come from the Google Books project and include over 5.8 million texts, more than $4 \%$ of books ever published (Michel et al. 20II).

in the archaeological record to methods for their recovery and analysis to diverse modes of interpretation, both alone and in concert with other types of archaeological analyses.

This book differs from prior contributions to the field in three ways. First, this is the only comprehensive edited volume focusing on method and theory to appear since the 1988 publication of Current Paleoethnobotany (Hastorf and Popper 1988), still an influential and frequently cited volume but now dated in bibliography and without the benefit of technical advances in the field since the r 980 . Due to the high quality of the chapters in that volume, we aim to supplement (rather than replicate) the topics covered in 1988 with new areas of inquiry (e.g., starch grain analysis, stable isotope analysis, ancient DNA, digital data management, and ecological and postprocessual theory) that have become central to contemporary archaeological debates. Second, we aim for worldwide coverage in the literature referenced, in contrast to many excellent recent volumes that synthesize regional bodies of data and literatures in 
the Northeastern United States (Hart 1999, 2008), the Eastern United States (Gremillion 1997; Minnis 2003; Scarry 1993b), the Western United States (Minnis 2004), China (Zhao 2010), Africa (van der Veen 1999b), the tropics (Hather 1994), and Europe and the Near East (van Zeist and Casparie I984; van Zeist et al. 199I). Finally, although Pearsall's (2000) Paleoethnobotany: $A$ Handbook of Procedures, currently in its second edition, is a critical reference for all paleoethnobotanists (as well as archaeologists of other specialties), its focus lies on providing a broad overview of methods in the discipline, rather than a critical examination of particular areas of study. This volume, in contrast, includes chapters that focus narrowly on individual topics and assesses the current state of theoretical, methodological, and empirical work in each area. We intend for this book to be used alongside the seminal works listed above, as well as myriad monographs and articles, and to serve as the next milestone along the path of paleoethnobotanical knowledge.

This chapter serves two purposes: it reviews briefly the state of the field to date and it suggests future directions in paleoethnobotany. Rather than list or summarize the other chapters in this volume, we reference them within this discussion to show how the questions addressed in subsequent chapters fit into the overall trajectory of both recent advances and predicted future trends in the field. Paleoethnobotany is poised at the intersection between study of the past and concerns of the present, including food security, biodiversity, and global environmental change, and has much to offer to archaeology, anthropology, and interdisciplinary studies of human relationships with the natural world. This volume, as a whole, illustrates many of these connections and highlights the increasing relevance of the study of past human-plant interactions for understanding the present and future (cf. van der Leeuw and Redman 2002).

\section{THE DEVELOPMENT OF PALEOETHNOBOTANY}

\section{The State of the Field in the i980s}

The state of the field of paleoethnobotany through the I980s is well summarized by books published late in that decade (Hastorf and Popper I988; Pearsall 1989; van Zeist et al. I99I) and need not be repeated here (see Ford 2003, 2004; Hastorf 1999:55-57; Pearsall 2000:I-IO; Popper and Hastorf I988; Renfrew 1973:I-6 for excellent summaries of this period). Early work in the field stemmed from chance finds of desiccated or waterlogged plant remains in archaeological contexts, the analysis of which first began in the late nineteenth century and continued through the I96os (Pearsall 2000:4-6). The 
major tipping point for the study of paleoethnobotanical remains was the application of flotation to recover carbonized plant remains from archaeological sediments, a technique suitable for a wide variety of archaeological contexts. First publicized to the American archaeological community in 1968 (Struever I968), flotation rapidly became adopted for use at an increasing number of sites across the Americas, Europe, and the Near East (Pearsall 2000:4-6). Coupled with the expansion of large salvage archaeology projects in the United States in the I970s and I980s (henceforth termed Cultural Resource Management, or $C R M$, projects), massive botanical data sets were recovered using flotation, studied, and published, driving the need for comprehensive methodological treatments of paleoethnobotany (i.e., Hastorf and Popper 1988; Pearsall 1989) that went beyond prior works that were more narrowly concerned with identification and interpretation of cultigens (e.g., Renfrew 1973; van Zeist and Casparie 1984).

Pearsall's (1989) and Hastorf and Popper's (1988) volumes had two farreaching implications for paleoethnobotanical research in the r99os and beyond. First, they popularized the study of plant remains as a theoretically grounded discipline that had the potential to address a variety of research questions. Chapters dealing with formation processes (Asch and Sidell I988; Pearsall I988), agricultural activities (Hastorf I988), paleoenvironmental reconstruction (Smart and Hoffman I988), and culture change (Johannessen I988) highlight some of the applications of paleoethnobotanical data sets. Second, these books explained the recovery of plant remains in a way accessible to the general population of archaeologists (Toll 1988; Wagner 1988; and especially Pearsall 1989 :chapter 2) and dealt with the basic quantitative methods employed in paleoethnobotanical analysis (Miller 1988; Pearsall 2000:chapter 3; Popper 1988). These references, and in particular the second edition of Pearsall's book, continue to be consulted by archaeologists during excavation as a "how-to" guide for the recovery of plant remains, especially when a paleoethnobotanist is not available to oversee sample collection and processing in the field. Undoubtedly these texts have contributed to the expansion of flotation and paleoethnobotanical analysis since the late r 980 .

\section{Trends in Paleoethnobotanical Analysis since i989}

We identify seven trends that have occurred in paleoethnobotany since the late I980s, leading to significant changes in the field today. We briefly outline these trends, and their implications, in this section. These trends include (I) improved understanding of the formation and depositional processes that 
affect botanical macro- and microremains; (2) improved methods for and frequency of paleoethnobotanical sampling, of both macro- and microremains; (3) new methods for quantification; (4) advances in computing and digital technologies, which have enabled new methods of interpretation; (5) the application of new theoretical approaches to the analysis of paleoethnobotanical remains; (6) the integration of paleoethnobotany with other methods of environmental archaeology; and (7) the increasingly mainstream role of paleoethnobotanical analyses and specialists within archaeological discourse. These trends are the result of a steady accumulation of knowledge within the field of paleoethnobotany, the increased number of trained paleoethnobotanists, and broader changes in the field of archaeology that have benefited paleoethnobotanical analysis.

\section{Improved Understanding of Formation and Depositional Processes}

Basic research continues on the processes that affect the deposition, decay, and preservation of botanical remains in a variety of archaeological contexts. These processes have not been a primary focus of earlier texts in the field (but see Pearsall 2000; Piperno 2006b; Torrence and Barton 2006). Five chapters in this book summarize recent advances in our understanding of the chemical, physical, and biological processes that affect botanical preservation at the macroscopic, microscopic, and biomolecular levels. Gallagher (chapter 2, this volume) describes both cultural and natural processes that affect the patterning of macrobotanical remains. Henry (chapter 3, this volume) and Pearsall (chapter 4 , this volume), in contrast, focus on the physical and chemical structure of botanical microremains (starch grains, and pollen and phytoliths, respectively) and recent experimental work that gives insight into how and why certain microremains may be preserved (or not) in specific archaeological contexts. Finally, Warinner (chapter I4, this volume) and Wales et al. (chapter I5, this volume) discuss the factors that influence biochemical and biomolecular (DNA, RNA, and protein) preservation in archaeobotanical remains. This basic knowledge has improved the ability of paleoethnobotanists to make claims about the presence and absence of certain taxa at the time of deposition, rather than at the time of analysis.

\section{Improved Paleoethnobotanical Sampling Methods and Increased Sampling Frequency}

The "flotation revolution" of the I97os was responsible for making the collection of plant remains a part of mainstream archaeological fieldwork in many parts of the world, as described above, and sampling has continued to 
increase ever since. This is mainly the result of the penetration of flotation, and other appropriate methods for recovering botanical remains, into parts of the world where such work was not previously practiced. Archaeologists in South and East Asia and Africa, in particular, have only recently begun to adopt flotation on a large scale (e.g., Crawford 2006, 2009; D'Andrea et al. 20or; D’Andrea 2008; Di Piazza I998; Fairbairn 2007; Fuller 2006; Fuller and Weber 2005; Gallagher 20I0; Kajale I99r; Lee et al. 2007; Logan 20I2; McConnell and O'Connor 1997; Neumann et al. 2003; van der Veen 1999b; Zhao 2010). Improvements in the identification and interpretation of microremains (here phytoliths and starch grains) from archaeological contexts, especially in tropical soils where macroremains are poorly preserved, have further expanded our understanding of plant use on a global scale (Denham et al. 2003; Fahmy 2008; Fahmy and Magnavita 2006; Pearsall 2000:chapter 5; Piperno 2006a, 2009; Piperno and Holst 1998; Torrence and Barton 2006). The availability of methods guides for sampling both macro- and microremains (Fritz 2005; Pearsall 2000; Piperno 2006b; Torrence and Barton 2006) has further increased the ubiquity of such sampling. D'Alpoim Guedes and Spengler (chapter 5, this volume) and White and Shelton (chapter 6, this volume) address recent trends in methods for sampling and recovering paleoethnobotanical remains, including recent improvements in flotation device efficiency and portability, such as the hand-pump flotation device (Shelton and White 2010).

\section{New Methods in Quantification}

An increase in computing technology and the development of statistical software programs have allowed major contributions to the quantification and interpretation of archaeological plant remains through multivariate statistics, especially correspondence analysis and various derivative methods (see discussion in A. Smith, chapter Io, this volume). These methods extract significant axes of variation from large and complex data sets and can be used for the direct integration of plant and animal remains from an archaeological site (VanDerwarker 20I0a). The interpretation of multivariate statistics remains subjective and such statistical methods are not appropriate for every data set (Jones 1991). Multivariate approaches, however, have been essential to new advances in understanding large-scale patterning of archaeological plant remains at both the sitewide and regional scales (e.g., Colledge et al. 2004; Jones et al. 20I0; Peres et al. 2010; Smith and Munro 2009; Torrence et al. 2004; van der Veen 1992a, 2007b; VanDerwarker 2006).

Improvements have also been made in the use of simple (i.e., non-multivariate) statistics and their applications to interpretation of paleoethnobotanical 
assemblages, especially related to hypothesis testing (see Marston, chapter 9, this volume). Such applications extend to the interpretation of both intrasite (VanDerwarker et al., chapter II, this volume) and intersite (Stevens, chapter $\mathrm{I} 2$, this volume) variation in the deposition of plant remains.

\section{Advances in Computing and Digital Technologies}

Perhaps no change over the past thirty years has affected archaeology as much as the exponential increase in computing power and the increased availability and usability of digital imaging on devices ranging from microscopes to multispectral satellites. As Warinner and d'Alpoim Guedes (chapter 8, this volume) discuss, these advances have had profound implications for the field of paleoethnobotany by enhancing our ability to record, store, sort, analyze, publish, and share the results of our analyses. Powerful desktop and portable computers make possible the widespread use of multivariate statistics, as described above, and spatial analysis, including the analysis of remotely sensed data (Casana, chapter I6, this volume). Online archives have enabled unprecedented sharing of data and publications (Warinner and d'Alpoim Guedes, chapter 8, this volume) and enhance the utility of reference collections (e.g., botanical collections imaged and available online in high resolution; Fritz and Nesbitt, chapter 7 , this volume). Computing advances have also greatly enhanced other areas of science, such as genomics, that have had tremendous implications for paleoethnobotany (Londo et al. 2006; Olsen and Schaal I999; Smith 200ra, 2014; Smith and Zeder 2013; Zeder, Bradley, et al. 2006; Zeder, Emshwiller, et al. 2006; see also Wales et al., chapter I5, this volume).

\section{New Theoretical Approaches}

The major theoretical shift in archaeology during the I980s and I99os that culminated in the division of theoretical approaches between so-called processual and postprocessual theoretical stances is one of the defining trends of archaeology as a whole over the past three decades, as have been attempts to find common cause between these approaches (Fogelin 2007; Trigger 2006). Paleoethnobotany has traditionally fallen into the "processual" camp, as the rise in scientific analysis during the I97os that included the flotation revolution was tied to the rise of the "New Archaeology" that formed the basis for processual approaches to archaeology (Trigger 2006; Watson et al. 1971). Paleoethnobotanical data, however, have always been amenable to a variety of interpretive approaches, and publications since the r 980 o highlight that variation. The application of "postprocessual" gender theory (Hastorf 199I) and 
Bourdieu's concept of habitus (Atalay and Hastorf 2006; Bourdieu 1977) to the interpretation of food remains has led to important insights into practices of food preparation and consumption, as well as the origins of agriculture (Asouti and Fuller 2013). Similarly, practice theory offers another approach to understanding the social setting for food preparation in the past (Morell-Hart, chapter 19 , this volume).

Other theoretical approaches derived from biology, and especially ecology, have been important avenues for understanding plant gathering, domestication, and crop selection. Human behavioral ecology, the study of how people make foraging decisions under particular environmental conditions, has offered new perspectives on hunting and gathering, transitions to agriculture, agricultural risk management, and settlement location (Gremillion, chapter I7, this volume; see also Bird and O'Connell 2006; Gremillion 2002a, 2002b; Gremillion and Piperno 2009a; Gremillion et al. 2008; Kennett and Winterhalder 2006; Marston 2009, 20II; Zeanah 2004). Niche construction theory, which addresses the ways in which people shape their environments and the ecological and social implications of such practices, informs our understanding of pre-agricultural practices, including incipient stages of domestication (B. Smith, chapter I8, this volume; see also Odling-Smee et al. 2003; Smith 2007a, 2007b, 2009a, 2009b, 201ra, 201rb). Combined with more traditional evolutionary approaches to understanding domestication (e.g., Rindos 1984), biological theory offers a counterpoint to social theory as a meaningful framework for interpreting paleoethnobotanical assemblages.

\section{Integrated Environmental Archaeology}

The term environmental archaeology, which describes the broad suite of methods used to understand human-environmental interaction in the past and includes paleoethnobotany, has been used increasingly to describe integrated paleoenvironmental and archaeological analyses over the past twentyfive years as these integrated approaches have become more common, generally outpacing the growth of both paleoethnobotany and zooarchaeology as a key term (figure 1.2; Dincauze 2000; Reitz et al. I996; Reitz et al. 2008). An integrated approach to environmental archaeology beginning at the stage of project design is highly recommended, as it allows for comprehensive sampling strategies and sharing of data between specialists, leading to a more nuanced understanding of human-environmental interactions in the past.

Recent publications have focused on the integration of animal and plant remains (Smith and Miller 2009; VanDerwarker and Peres 2010), a topic not addressed in this volume, but the integration of other environmental 


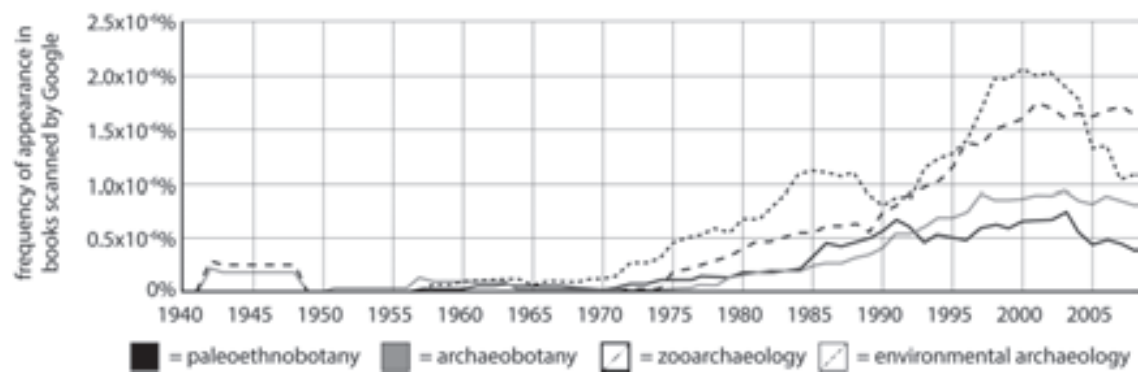

FigURE 1.2. Relative trends in the use of the terms paleoethnobotany, archaeobotany, zooarchaeology, and environmental archaeology in English-language books published between 1940 and 2008, using Google Ngram Viewer (https://books.google.com/ngrams, searched May 30, 2013). These data come from the Google Books project and include over 5.8 million texts, more than $4 \%$ of books ever published (Michel et al. $20 I I$ ).

archaeology techniques with paleoethnobotanical analysis has been pursued less often. Several chapters of this volume address how botanical remains can be used in concert with other data sets, including soil chemistry and geomorphology (Messner and Stinchcomb, chapter I3, this volume), human and plant stable isotope data (Warinner, chapter I4, this volume), and remote sensing satellite imagery (Casana, chapter $\mathrm{I} 6$, this volume). New methods and applications in the fields of genetics and proteomics are also presented, with an emphasis on the use of botanical remains in ancient DNA and paleoproteomic studies (Wales et al., chapter I5, this volume).

\section{Paleoethnobotany Becomes Mainstream}

Although paleoethnobotanists, much like other environmental archaeologists and archaeological scientists, were once considered specialists restricted to the analysis of specific bodies of data, now many paleoethnobotanists direct or codirect archaeological projects, putting paleoethnobotanical research questions at the forefront of excavation goals. A review of articles published since 1990 in American Antiquity, the flagship journal of the Society for American Archaeology and a methods-agnostic forum for publication of North American archaeology, shows an increase in publications that incorporate paleoethnobotanical methodologies in the mid-late I990s (figure I.3).

This period, the five to ten years following the publication of both Current Paleoethnobotany (Hastorf and Popper 1988) and Paleoethnobotany: A Handbook 


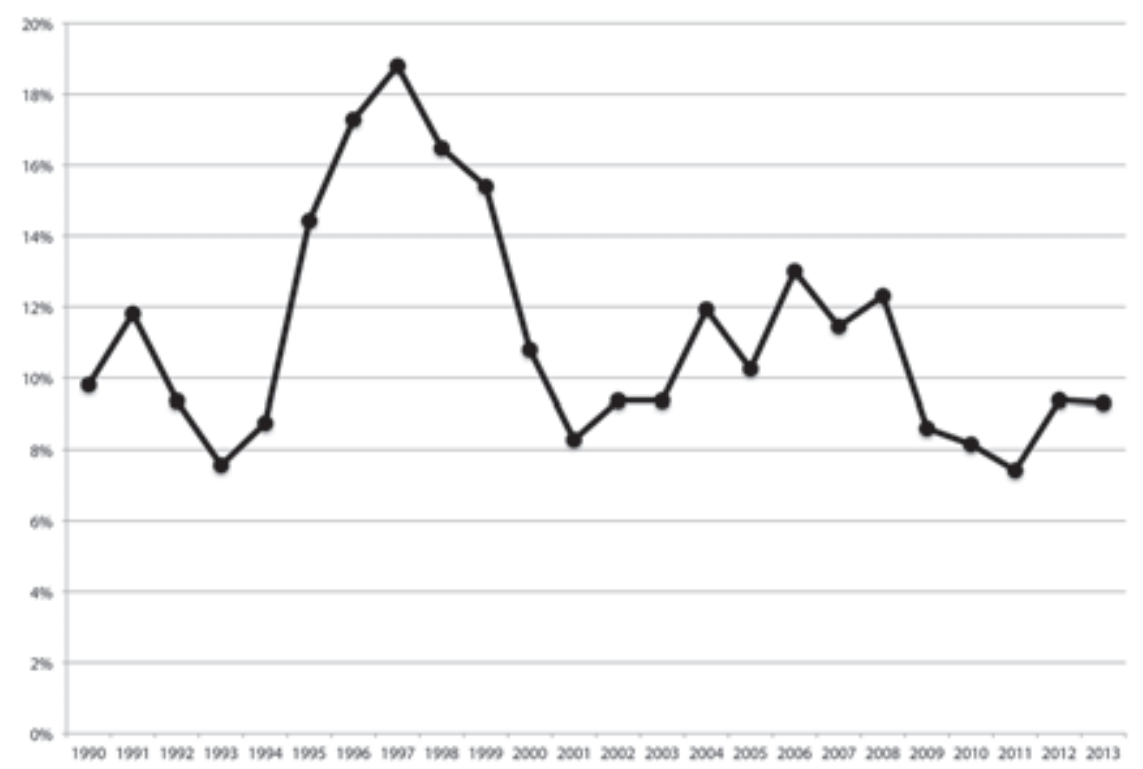

FIGURE I.3. Trends in the frequency of paleoethnobotany as a major research component of research articles published in American Antiquity between 1990 and 2013 (through April issue), represented as the three-year trailing average of the percentage of total research articles published (e.g., the 1990 data point is the average of the years 1988, 1989, and 1990).

of Procedures (Pearsall 1989), also saw the publication of several major edited volumes in the field (e.g., Gremillion 1997; Hart 1999; Scarry 1993a). Since 2000, the number of articles focused on paleoethnobotany in American Antiquity has remained relatively constant at around io percent of the total. US National Science Foundation (NSF) funding for paleoethnobotanical research peaked during the early I990s, after which funding rates for projects incorporating paleoethnobotany stabilized to approximately $5^{-20}$ percent of the total (figure I.4).

Since 1988 , the NSF has supported more than 200 projects involving paleoethnobotanical research, representing approximately i4 percent of all funded archaeological projects. ${ }^{1}$ For more than half of these projects, paleoethnobotanical analysis is a major component of the project and is fundamental to the project goals. We suggest that the evident "bump" in NSF-funded paleoethnobotany projects between 1990 and 1993 may have further contributed to the increase in paleoethnobotanical articles published in American Antiquity between 1995 and 1999 (figures I.3 and I.4). The $\mathrm{PhD}$ students who have been 


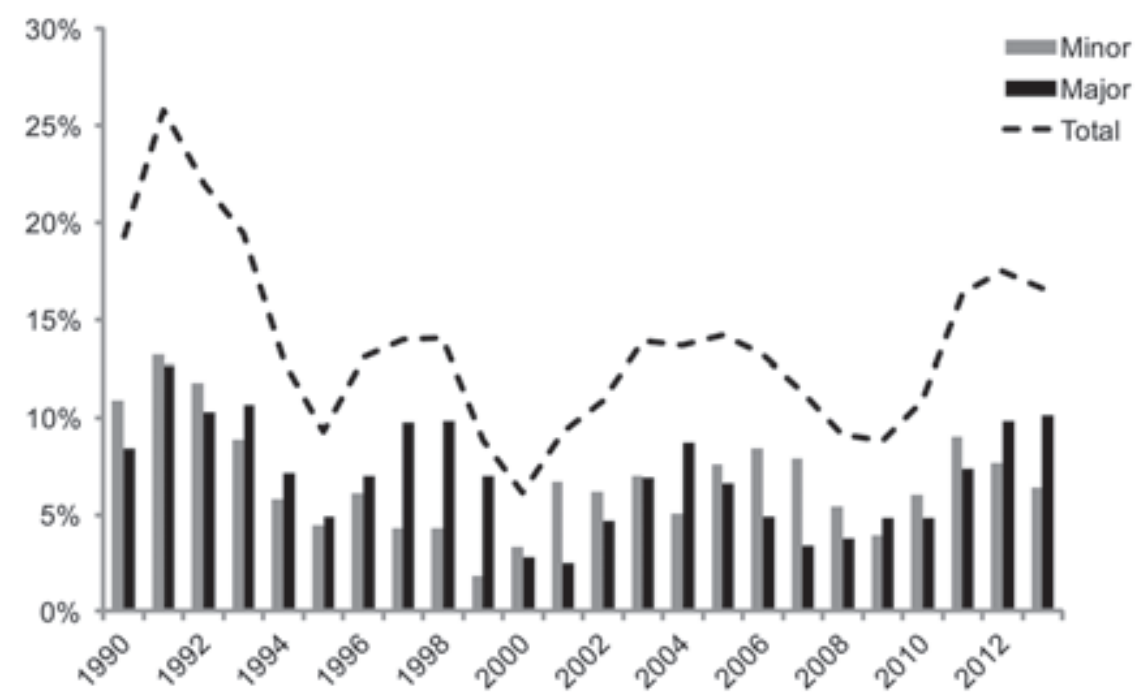

Figure 1.4. Trends in the frequency of NSF-funded projects involving paleoethnobotanical research, I988-20I3, represented as the three-year trailing average of the percentage of total NSF-funded archaeology projects (e.g., the 1990 data point is the average of years 1988, 1989, and 1990). The contribution of paleoethnobotanical inquiry to the project as a whole was scored as major or minor.

trained on these projects have gone on to start their own integrative, multidisciplinary projects, leading to an expansion of the use of botanical data in mainstream archaeological publications and a broadening of questions that paleoethnobotanical methods and data are used to address.

\section{FUTURE DIRECTIONS IN PALEOETHNOBOTANY}

According to an often-quoted line, it is always difficult to make predictions, especially about the future. Nonetheless, we see many of the trends listed above continuing into the future, in particular those related to increased collection and study of botanical remains, and further integration of paleoethnobotany with other environmental archaeology methods, especially those operating at the molecular level. In addition, we suggest three new ways in which we see the field of paleoethnobotany changing over the next twenty to thirty years: (I) increased accessibility of published data sets online, leading to broader-scale (and more powerful) analyses; (2) increased training 
of paleoethnobotanists in developing countries and more publications from those countries; and (3) increased relevance of paleoethnobotany beyond archaeology, particularly in environmental and climate-change science. We outline briefly why we see these as likely future directions for the field and how we see these developments affecting the practice of paleoethnobotany and its role within archaeology.

\section{Increased Accessibility of Paleoethnobotanical Data Sets}

The Internet has proven to be a remarkable tool for sharing primary data sets. Well-managed public scientific data repositories, such as GenBank, have transformed research in other fields (e.g., evolutionary genetics and genomics), and similar databases show promise for improving archaeological practice as well (see Warinner and d'Alpoim Guedes, chapter 8, this volume). Existing paleoethnobotanical database websites host images (e.g., Paleobot. org) and distributional maps (e.g., the Archaeobotanical Database of Eastern Mediterranean and Near Eastern sites, http://www.cuminum.de/archaeobotany), as well as bibliographic references (e.g., Literature on Archaeological Remains of Cultivated Plants I98I-2004, http://www.archaeobotany.de/). The Archaeobotany Listserv (https://www.jiscmail.ac.uk/cgi-bin/webadmin?AI $=$ ind $4007 \& \mathrm{~L}=\mathrm{ARCHAEOBOTANY}$ ) accomplishes similar goals through email communication. In addition, the deposition of entire primary data sets into online data repositories such as PANGAEA, tDAR, OpenContext, and DRYAD is increasingly being encouraged by scientific journals and government funding bodies (see Warinner and d'Alpoim Guedes, chapter 8, this volume).

The possibility offered by centralized data repositories of primary archaeobotanical data is reuse of published data sets, which remains uncommon in the field, and integration of data sets to produce regional syntheses (e.g., Miller and Marston 2012). This has the potential to reduce Balkanization of the field and contribute to larger-scale and more powerful statistical analyses, leading to more significant and meaningful results. We see ongoing trends in computing and digital visualization contributing to this goal, allowing better sharing and more rapid analysis of large data sets. Perhaps most important, should governmental regulations for CRM institute mandatory digital archiving in a limited number of permanent online data repositories, such as those listed above, large numbers of botanical data sets that have been buried in gray literature will become accessible and contribute to future paleoethnobotanical research. 
Increased Training in and Adoption of

Paleoethnobotany in Developing Countries

Paleoethnobotany has historically been practiced by North Americanor European-based scholars working in traditional areas of archaeological focus: the Americas, Europe, and the Mediterranean and Near East. Naomi F. Miller's 2oro survey of archaeobotanists identified 86 percent of respondents (total number of respondents was II8) as being based in North America (United States or Canada), the British Isles, or mainland Europe. Similarly, only to percent of respondents described their primary geographic area of specialty as something other than the Americas, Europe, or the Mediterranean and Near East (Miller 20I0a:22; 20Ira:Io). Until the last two decades, nontraditional areas such as East and South Asia, Sub-Saharan Africa, Oceania, and the tropics of both the New and Old Worlds were studied infrequently and only by a few scholars. This is changing today and will continue to change as more paleoethnobotanists are trained in those countries and go on to careers in archaeology. Even a small number of well-trained specialists can have a dramatic impact on the amount of data analyzed in a developing country, and continued partnerships with well-established scholars in North America and Europe will facilitate publication and dissemination of the results of those analyses. Furthermore, training new generations of scholars with distinct educational and cultural backgrounds will broaden the diversity of the field and allow the practice of paleoethnobotany to move in new directions not previously pursued. More than any other trend, the growth of scientific archaeology worldwide will have tremendous implications for the future of paleoethnobotany and our collective understanding of the human past.

\section{Relevance of Paleoethnobotany beyond Archaeology}

Research attention (and funding) in many fields has moved toward understanding the human role in global environmental change, including climate change, and the future implications of ongoing present-day interactions between people and their natural environments. One thread in this research has focused on the past, partly to establish an accurate baseline for natural processes of climate change and extinction events in the pre-human past, and partly to establish how humans affected environmental systems in the pre-industrial period (Foley et al. 2005; Jackson et al. 200I; Lotze 2010; Pauly 1995). Archaeology as a whole has much to offer this effort, as it is the one discipline that directly investigates the holistic past across the entire span of human existence (Redman et al. 2004; van der Leeuw and 
Redman 2002). Paleoethnobotany has a major role to play in this endeavor by providing robust data sets that reflect interactions between human and botanical communities over long spans of time and across economic, social, geographic, and climatic transitions. Recent work in the field highlights the value of such data: for example, synthetic analyses of long-term coupled changes in both human societies and vegetation communities in the Near East, as reconstructed through both macrobotanical (Riehl 2009) and pollen analysis (Rosen 2007), have clarified how climate and environmental change influenced agricultural practices on a regional scale over time. In some cases, however, paleoethnobotanical data are still largely neglected in the study of environmental change associated with agricultural systems (e.g., the case studies in Fisher et al. 2009), offering an opportunity for increased future contributions for paleoethnobotany.

\section{CONCLUSIONS}

Paleoethnobotanical inquiry is a rich and varied field, providing everything from basic science on depositional processes to interpretation about human adaptation to local environments on a global scale. The field has expanded in the number of practitioners, frequency of sampling and analysis, areas of the world in which such work is routinely conducted, and breadth of research questions addressed. The flotation revolution of the I97os is still expanding in Africa and Asia, and the theoretical debates of the I980s have brought a multivocal perspective to the interpretation of plant remains. In addition, the technological improvements of the I990s and 2000 s have led to unprecedented opportunities for data analysis, publication, and sharing. This volume highlights the implications of these developments and complements earlier volumes in the field that have driven research inquiry over the past quarter century.

Furthermore, we argue that the field is poised for further contributions to study of not only the human past but also the human present and future. We believe that paleoethnobotanical data sets are rich and robust sources of information on human adaptation to climate change and offer case studies of successful and unsuccessful agricultural and land-use systems in the past that are directly relevant to assessing the sustainability of such systems in the present. Despite persistent challenges in funding, employment, and integration with other areas of archaeology and the social and natural sciences (Miller 2orra:9), paleoethnobotany is poised for a new set of revolutions. We hope this volume contributes to that bright future. 


\section{NOTE}

I. Survey conducted on all active and expired records with start dates from I988 to 2013 with the Field of Application = anthropology and/or Search Award For = archaeology. The first complete year for which the public NSF project records include abstracts, allowing project content statistics to be calculated, is I988. Abstracts for records related to archaeology and including the terms botan*, plant, or flora were then read and scored for content. The paleoethnobotanical content of each abstract was scored as: $\mathrm{o}=$ none, $\mathrm{I}=$ minor, and 2 = major. Projects were deemed as having paleoethnobotanical content if they involved the direct investigation of ancient plant remains (macroscopic, microscopic, biomolecular, or biochemical) or involved targeted work towards producing modern reference collections or data sets for the interpretation or modeling of ancient plant remains. Surveys of modern vegetation without the purpose of being used for paleoethnobotanical interpretation were excluded. 